\title{
COMPARATIVE ANALYSIS OF THE SYSTEM AND MECHANISMS TO SUPPORT THE DEVELOPMENT OF AGRI-FOOD EXPORTS IN UKRAINE AND THE EU
}

Iryna TYTARCHUK, National University of Kyiv-Mohyla Academy, 08162 Kyiv region, village Chabany, Mashynobudivnykiv St, 1B, Ukraine, tytarchuk_ira@ukr.net (corresponding author)

Yelyzaveta BIELIAIEVA, National University of Life and Environmental Science of Ukraine, 08171 Kyiv region, village Khotiv, Bohdana Khmelnytskoho St, 1, Ukraine, Elizaveta.belyaeva@ukr.net

\begin{abstract}
The role of government programs and measures to stimulate exports is becoming increasingly important in the development strategies of countries, especially developing countries, which seek to make exports the engine of economic growth. At the same time, coordinated institutional work to stimulate exports is considered to be the most important factor to ensure comprehensive diversification of foreign trade activities. For the agricultural sector of Ukraine, the matter of systematic work to support and promote exports is currently extremely relevant.

The main research methods within the study are surveys, SWOT-analysis, GAP-analysis, consolidation of information, comparison of export support activities in Ukraine and the EU.

The results of the study demonstrate Institutions and Tools of State Export Support in Ukraine and the EU, export-oriented services by of support institutions, export support activities carried out by various institutions, practices on national export promotion activities comparison of Ukraine with the countries of the European Union (Republic of Ireland, Kingdom of the Netherlands, Federal Republic of Germany).

The main conclusions of the study are formed by areas - on the one hand Public Authorities, and on the other for Business Support Institutions, Unions and Associations. The recommendations cover areas such as the general coordination of export promotion programs, building a global network of local offices, access to finance, online services and informational Internet portals, presenting the organization on the Internet, marketing and communication strategies, improving the quality of export support services, providing financial support to enterprises entering new markets
\end{abstract}

Keywords: economic growth, agri-food sector, export support, export development, local business support

\section{INTRODUCTION}

Over the last decade, the agri-food complex has undoubtedly become one of the key sectors of Ukraine's economy, generating about $17 \%$ of the country's GDP annually. Despite the crisis, the agri-food complex (AIC) remained one of the drivers of support and growth of Ukraine's economy, maintaining a positive growth rate of production. Compared to 2013, in 2019 the volume of agricultural production in Ukraine increased by more than $11 \%$.

Since 2013, agricultural products have remained the largest export group. However, despite the trend of increasing exports of agricultural products, this process still has a number of problems, namely: excessive raw material orientation and low share of agricultural products with high added value in the structure of domestic agricultural exports; slow integration of domestic agri-food complex into food segments of the world agricultural market; weakness of the system policy of forming a positive image and promotion of agricultural products in foreign markets; and underdeveloped network (Export Promotion..., 2019; Ukraine Investment..., 2019).

Object of the study is perception of the export-enabling efforts in Ukraine and the EU, current status of export support, and general outlooks of the export development from the point of view of agricultural and food experts. Research aim is to research opportunities that the local business support offices, education institutions and government can provide agro-business.

Focusing on further maintaining the high rate of increase in agricultural production, the Government of Ukraine aimed to create and implement a new agricultural exports support policy, aimed at increasing exports of value-added products. In 2017, a national export strategy was adopted, which recognized the food and processing industry as one of the strategic sectors with the greatest prospects for increasing export volumes. In 2019, a sectoral 'agricultural' export strategy was adopted, which determined the directions of development of exports of agricultural products, food and processing industries of Ukraine for the period up to 2026. Also, over the last three years, several important government

Copyright (C) 2021 The Authors. Published by Vytautas Magnus University. This is an open-access article distributed under the terms of the Creative Commons Attribution License (CC BY 4.0), which permits unrestricted use, distribution, and reproduction in any medium, provided the original author and source are credited. 
authorities, the Export Promotion Office and the Export Credit Agency, have been established; their work is aimed at supporting and promoting the export of Ukrainian products in general.

At the same time, world experience shows that the creation of an effective and efficient system to support and promote exports solely through the state is impossible, as it requires the development of a wider external and internal institutional network, which will involve as many stakeholders to the export activity (Zhu, Fu, 2013).

In recent years, several studies have developed different indices to measure the sophistication of a country's exports and thereby examine the determinants and impact of export upgrading. It has been found that there is a robust positive effect of export sophistication on a country's economic growth, per capita income, and human capital.

It is important for a company that wants to market their products and services in other countries, to consider local culture and local language, thus to be able to find a strategic position successfully in the market. Companies face many challenges on the market, not only in terms of marketing products or services. They must have an effective planning program, and develop effective strategies for sourcing, transportation, marketing activity, with demands and results that differ from one country to another, subject to different regimes related to trade policies, legislation, infrastructure, culture, etc. Also, companies need to be socially and environmentally responsible, requiring to engage in these actions for the good of society, but also to build a successful business (Surugiua, Surugiu, 2015).

For example, the Government of the United Kingdom has approved an Export Strategy: supporting and connecting businesses to grow on the world stage, in order to form a trade policy and setting out a new framework for UK trade. Leaving the European Union means the feasibility pursue an independent trade policy, to maximise trade opportunities across the world and deliver benefits for business, workers and consumers around the whole of the UK The main obstacles that hinder enterprises from entering new markets will be taken into account: not believe they are suited to overseas sales, lack the confidence to pursue them; a lack of knowledge or capacity to pursue exporting opportunities; issues such as customs procedures, non-tariff barriers and local regulations; and access to trade and export finance (HM Government, 2018).

Therefore, to determine the next steps of Ukraine to build an appropriate institutional network, it is extremely important to assess the current state of development and interaction of the existing institutional units of the export support network in Ukraine, as well as study the experience of incentives and organization of such institutional networks.

\section{RESEARCH METHODS}

To address the above in the prerequisites of the study issues, a survey was conducted of organizations that provide services to support and develop export activities. The questionnaire sought to study the overall perception of the current and expected situation with the export support. All questions were meant to explore and consolidate respondent' data on the organization's profile, core operations, strengths, weaknesses, needs, opportunities, as well as the expected and overall changes in the organization's operations.

Within the study were used SWOT analysis and GAP analysis tools for questionnaire development and further information analysis. These tools designed for use in the preliminary stages of decision-making processes and can be used as tools for evaluation of the strategic position of organization. GAP and SWOT analysis intended to specify the objectives of the business venture or project and identify the internal and external factors that are favorable and unfavorable to achieving.

SWOT-analysis allows you to create significant advantages, disadvantages, opportunities and threats, which helps to determine the competitive characteristics of the organization. Gap analysis identifies gaps between the optimized allocation and integration of the inputs (resources), and the current allocation-level.

\section{RESEARCH RESULTS}

The agricultural sector of the economy, showing signs of stabilization, has strong growth potential in domestic and foreign markets. The volumes of agricultural production in Ukraine are included in the forecasts of the dynamics of world prices for food resources. High integration of Ukraine's agri-food complex into the world economic space requires monitoring of foreign trade in agricultural and food products in order to timely identify threats to food security and prevent negative phenomena in this area, as well as state policy aimed at strengthening Ukraine's position in traditional foreign markets, developing promising markets, as well as increasing exports of products with higher value added.

SMEs notably find it difficult to overcome the fixed costs related to entering new markets or to entering new product segments. Evidence from the OECD-WTO AFT monitoring survey (OECD/WTO, 2019) indicates that technical assistance can play a powerful role in helping suppliers in developing countries to increase competitiveness and to connect to value chains. Indeed, the survey evidence suggests that where labour skills development efforts are delivered as an element of aid-for-trade support, private and public sector actors consider them to be effective in helping local suppliers to connect to or to move up within value chains (Jansen, Lanz, 2013).

Ukraine has an extensive legal framework for export promotion, institutional support, a set of non-financial tools of indirect action, but all of them are of general economic nature, do not take into account agricultural specifics and have limited tools to promote AIC products. 
Table 1. Institutions and Tools of State Export Support

\begin{tabular}{|c|c|c|}
\hline Areas & General economic sphere & Agricultural sector \\
\hline Basic legislation & $\begin{array}{l}\text { Export Strategy of Ukraine ('Road map' of } \\
\text { strategic trade development) for 2017-2021 } \\
\text { Is put into force, the results and a schedule can } \\
\text { be found on the MDETA website. }\end{array}$ & $\begin{array}{l}\text { The Strategy for the development of exports of } \\
\text { agricultural products, food and processing industries } \\
\text { of Ukraine until } 2026 \text {. } \\
\text { [Its] Execution is fragmentary and non-systematic, } \\
\text { any performance monitoring is missing. } \\
\text { Sectoral export strategy } 2019-2023 \text { for the food and } \\
\text { processing industry of Ukraine. } \\
\text { Has a narrow sphere of influence, only some } \\
\text { subsectors of the food industry. }\end{array}$ \\
\hline Support institutions & $\begin{array}{l}\text { MDETA, MFA, Departments for economic } \\
\text { issues within the diplomatic missions of Ukraine } \\
\text { abroad }\end{array}$ & $\begin{array}{l}\text { MDETA } \\
\text { The provision states that it participates in the } \\
\text { development and implementation of measures to } \\
\text { increase the export potential of agro-industrial } \\
\text { production. } \\
\text { State Service of Ukraine for Food Safety and } \\
\text { Consumer Protection } \\
\text { Through the Minister of the MDETA, activities are } \\
\text { directed and coordinated, providing the minimum } \\
\text { necessary conditions for the promotion of Ukrainian } \\
\text { agricultural exports in foreign markets in terms of } \\
\text { sanitary and phytosanitary measures. } \\
\text { There are no specialized agricultural institutions. }\end{array}$ \\
\hline $\begin{array}{l}\text { Specialized support } \\
\text { institutions }\end{array}$ & $\begin{array}{l}\text { International Trade Council under the Cabinet of } \\
\text { Ministers of Ukraine, Export Promotion Office } \\
\text { of Ukraine (it is planned to create a state agency } \\
\text { for business development, with 'exports' as a } \\
\text { separate component), Exporters and Investors } \\
\text { Council at the Ministry of Foreign Affairs of } \\
\text { Ukraine, Export Support Center (Ukraine-EU } \\
\text { Helpdesk) of the EU Delegation to Ukraine, } \\
\text { SMEs Development Office }\end{array}$ & Specialized agricultural institutions are missing. \\
\hline Financial instruments & $\begin{array}{l}\text { Export Credit Agency } \\
\text { De facto it does not operate. }\end{array}$ & $\begin{array}{l}\text { Export Credit Agency } \\
\text { De facto it does not operate. It has a limited impact } \\
\text { on the agri-food sector, only four product groups of } \\
\text { the Ukrainian Commodity Coding System are } \\
\text { supported: } 16,19,20 \text {, and } 21 \text {. }\end{array}$ \\
\hline $\begin{array}{l}\text { Non-financial tools: } \\
\text { exhibitions, analytics, } \\
\text { publishing, branding }\end{array}$ & $\begin{array}{l}\text { Export Promotion Office (to be transformed into } \\
\text { the Agency for Entrepreneurship and Export } \\
\text { Development), Exporters and Investors Council } \\
\text { at the Ministry of Foreign Affairs of Ukraine, } \\
\text { Export Support Center of the Delegation of } \\
\text { Ukraine to the EU (Ukraine-EU Helpdesk) } \\
\text { Export brand of Ukraine, UkraineNow }\end{array}$ & $\begin{array}{l}\text { Specialized agricultural institutions are missing. } \\
\text { There is no specialized agricultural branding. } \\
\text { Indirectly, the development of product recognition is } \\
\text { carried out through a system of products with a } \\
\text { geographical indication. }\end{array}$ \\
\hline
\end{tabular}

Source: Agritrade Ukraine... (2021)

The responsibility for the development of export promotion is scattered not only among state institutions, but also structurally divided even within the MDETA. That is, there are risks of some inconsistency and incoordination. Despite the developed legal framework, in reality the subject of state export promotion, especially agricultural one, does not have a strong position in Ukraine.

According to the study Analytical Report of Institutional Export Support in Ukraine the most common types of activities of the organizations operating in the agricultural sector and focusing on the promotion and development of agricultural exports include the following (figure 1).

As part of their activities, these organizations face the problem of their own positioning and representation in the market, limited and insufficient advertising and marketing budgets, and therefore have corresponding consequences in creating and maintaining a reputation. Also, business representatives are wary of all services provided by such organizations, due to lack of confidence in their quality and clear definition of directions (including export). At the same time, challenges for organizations that develop and support SMEs and provide export consultancy services are lack of practical experience of employees, low level of business English, imperfect knowledge of export-import legislation, limited access to market information, lack of analytical and methodological materials for providing quality consultations, and a limited number of partners for cooperation (including foreign ones). 
Provision of export-related information

Legal information and counselling

Participation in exhibitions

Publications

Webpage / online services

B2B-platforms

Trade representation

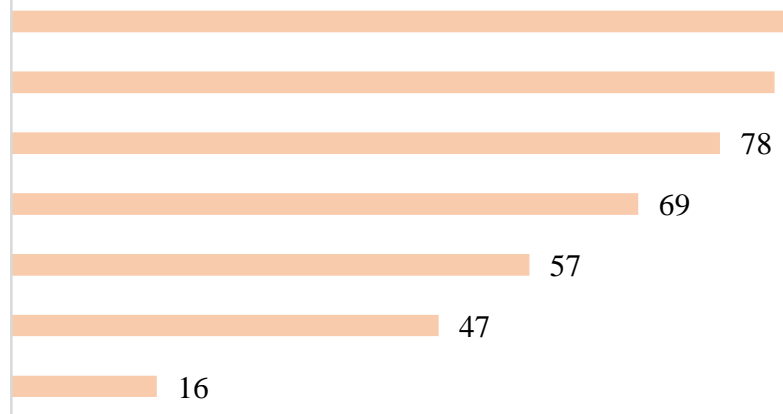

Figure 1. Export-oriented services by of support institutions, $\%$ of surveyed enterprises

In Ukraine, institutional support for business is provided by the following organizations (table 2): the Chamber of Commerce and Industry of Ukraine, regional Chambers of commerce and industry, business associations, industry associations, relevant public organizations, consultancy agencies, advisory services, and associations.

Table 2. Export support activities carried out by various institutions

\begin{tabular}{|c|c|c|c|c|c|c|c|c|c|c|}
\hline & 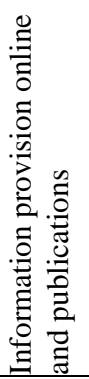 & 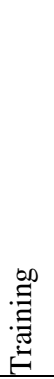 & 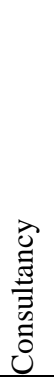 & 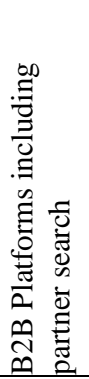 & 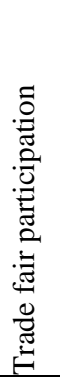 & 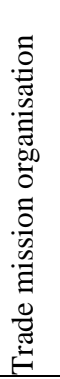 & 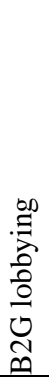 & 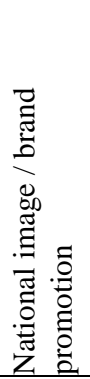 & 节 & 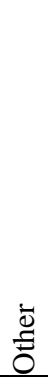 \\
\hline Entrepreneurship and Export Promotion Office & + & + & + & + & & + & + & + & & \\
\hline Ukrainian Chamber of Commerce and Industry & + & + & + & + & + & + & + & & + & \\
\hline Chambers of Commerce and Industry (x 28) & + & + & + & + & + & + & & & + & \\
\hline European Business Association & + & & & + & & & + & + & & \\
\hline Ukrainian Agribusiness Club & + & & & + & & & + & + & & \\
\hline $\begin{array}{l}\text { State-Owned Enterprise } \\
\text { "DerzhZovnishInform" }\end{array}$ & + & & + & & + & & & & & \\
\hline Ukrainian Agrarian Council & + & + & + & & & & + & & & \\
\hline Ukrainian Food Export Board & + & & & + & + & & & + & & \\
\hline Ukrainian Agrarian Confederation & & + & & & & & + & & & \\
\hline Vertical (product or sectoral) Associations & + & + & + & + & + & + & + & & + & + \\
\hline She exports & + & + & & + & + & & + & & & \\
\hline Fit for Partnership with Germany & & + & + & + & & & & & & \\
\hline $\begin{array}{l}\text { Promotion of a Supportive Framework for } \\
\text { Trade in Ukraine }\end{array}$ & + & + & & & & & & & & + \\
\hline Eu4business in Ukraine & + & & + & & & & & & & \\
\hline Agritrade Ukraine & + & + & & & + & + & + & & & \\
\hline $\begin{array}{l}\text { Supporting the implementation of agricultural } \\
\text { and food policies in Ukraine }\end{array}$ & + & + & & & & & & & & + \\
\hline Geographical Indications in Ukraine & & & + & & & & + & + & & \\
\hline UkrAgroConsult & + & & + & & & & & & & \\
\hline Association of exporters and importers & & & + & + & + & & + & & + & \\
\hline
\end{tabular}

Source: Agritrade Ukraine... (2021)

Associations, organizations and consulting centers that provide their services or consultations in response to requests from businesses also play an important role in supporting Ukrainian enterprises. Business associations are nonprofit voluntary associations of business entities that meet both the individual and general group needs of their members. The business association also acts as an element of infrastructure that promotes business development: it protects the rights and lobbies the interests of its members. The challenge for such organizations is their weak financial capacity and diversification of funding sources (membership fees and business orders).

As the experience of other countries shows, the philosophy of developing the idea of export support is inextricably linked with the general vision of the development of the agricultural sector, its place in the economy and society. In all three countries included in the study, there is one thing in common - namely, the presence of line Ministries that form a strategic vision of the sector and act, on the one hand, as an 'entry point' of the interests of a wide range of participants, and on the other hand, as a coordinator and customer of certain mechanisms of regulating these interests (table 3 ). 
Table 3. Practices on national export promotion activities

\begin{tabular}{|c|c|c|c|c|}
\hline Activities & Republic of Ireland & $\begin{array}{l}\text { Kingdom of the } \\
\text { Netherlands }\end{array}$ & $\begin{array}{c}\text { Federal Republic of } \\
\text { Germany }\end{array}$ & Ukraine \\
\hline \multicolumn{5}{|c|}{ Strategic level } \\
\hline $\begin{array}{l}\text { Strategic } \\
\text { documents for } \\
\text { agro export } \\
\text { promotion }\end{array}$ & Yes & No & No & Yes \\
\hline $\begin{array}{l}\text { Authority that } \\
\text { carries out the } \\
\text { general } \\
\text { coordination for } \\
\text { agro export policy }\end{array}$ & Yes & No & No/yes & No/yes \\
\hline Key actors & $\begin{array}{l}\text { "Bord Bia" (Irish } \\
\text { Food Board), } \\
\text { "Enterprise Ireland", } \\
\text { "Competitive } \\
\text { Feasibility Fund - } \\
\text { Agri Business" }\end{array}$ & $\begin{array}{l}\text { "Netherlands Enterprise } \\
\text { Agency", "Atradius Dutch } \\
\text { State Business", "Dutch } \\
\text { Trade and Investment } \\
\text { Fund" (DTIF), "Dutch } \\
\text { Good Growth Fund" }\end{array}$ & $\begin{array}{l}\text { BMWi, BMEL, Federal } \\
\text { Department of } \\
\text { Agriculture and Food } \\
\text { (BLE), Germany Trade } \\
\text { and Invest (GTAI), } \\
\text { German Chambers of } \\
\text { commerce abroad } \\
\text { (AHK), "Euler Hermes } \\
\text { Aktiengesellschaft" }\end{array}$ & $\begin{array}{l}\text { MDETA, Ministry of } \\
\text { Foreign Affairs of } \\
\text { Ukraine (MFA), } \\
\text { International Trade } \\
\text { Council under the } \\
\text { Cabinet of Ministers of } \\
\text { Ukraine (IT Council), } \\
\text { Export Promotion Office } \\
\text { of Ukraine (EPO) - the } \\
\text { agency will be } \\
\text { coordinated by the } \\
\text { Deputy Prime Minister, } \\
\text { the Minister of Digital } \\
\text { Transformation, } \\
\text { Exporters and Investors } \\
\text { Council under the MFA } \\
\text { of Ukraine (EIC), Export } \\
\text { Credit Agency }\end{array}$ \\
\hline $\begin{array}{l}\text { Agro export } \\
\text { abroad support / } \\
\text { agrarian attaché }\end{array}$ & Yes & Yes & Yes & No \\
\hline \multicolumn{5}{|c|}{ Support instruments for export promotion } \\
\hline Advice & $\begin{array}{l}\text { Free as well as paid } \\
\text { consultancy services, } \\
\text { trade mission support }\end{array}$ & $\begin{array}{l}\text { Free as well as paid } \\
\text { consultancy services, } \\
\text { special offers tools (SIB) } \\
\text { for doing business abroad } \\
\text { for Dutch SMEs }\end{array}$ & $\begin{array}{l}\text { Free as well as paid } \\
\text { consultancy services, } \\
\text { image promotion } \\
\text { activities in foreign } \\
\text { markets, market trips, } \\
\text { etc. }\end{array}$ & $\begin{array}{l}\text { There are no paid } \\
\text { consultancy services. As } \\
\text { part of the work of the } \\
\text { EPO, exporters are } \\
\text { provided some } \\
\text { consulting and } \\
\text { information assistance }\end{array}$ \\
\hline Information portal & Yes & Yes & Yes & No \\
\hline Funding & $\begin{array}{l}\text { Grant and financial } \\
\text { support }\end{array}$ & $\begin{array}{l}\text { Export credit insurance } \\
\text { In addition: guarantees, } \\
\text { loans, export financing, } \\
\text { form of export subsidies. }\end{array}$ & $\begin{array}{l}\text { Export credit guarantees } \\
\text { (Hermes insurance) }\end{array}$ & $\begin{array}{l}\text { Export Credit Agency } \\
\text { (ECA) }\end{array}$ \\
\hline $\begin{array}{l}\text { Coaching with } \\
\text { state support }\end{array}$ & Yes & Yes & Yes & No \\
\hline $\begin{array}{l}\text { Programs and } \\
\text { other }\end{array}$ & $\begin{array}{l}\text { Quality Assurance } \\
\text { Schemes } \\
\text { Origin Green }\end{array}$ & $\begin{array}{l}\text { SIB Market entry voucher } \\
\text { SIB Mission voucher } \\
\text { SIB Knowledge voucher } \\
\text { SIB Coaching voucher } \\
\text { SIB Individual trade fair } \\
\text { participation }\end{array}$ & $\begin{array}{l}\text { Associations are also a } \\
\text { direct 'participant' in } \\
\text { government programs } \\
\text { and measures to support } \\
\text { exports and other. }\end{array}$ & $\begin{array}{l}\text { Ukraine-EU Export- } \\
\text { Import Helpdesk }\end{array}$ \\
\hline
\end{tabular}

Source: Agritrade Ukraine... (2021)

Summarizing, "Irish agrarian success" in promoting exports is based on five components, namely: thoughtful actions, clear formulation of interests, awareness of their own potential and opportunities, prioritization of goods and markets, and all this is enshrined in legislation; availability of a specialized agricultural export agency Bord Bia and the organization for direct support of the enterprise - Enterprise Ireland; strong work on branding of the food group of goods; close coordination between state institutions, and presence of a wide network of foreign offices of the above organizations.

It should be noted that in the Netherlands there are no specialized programs and institutions within the country aimed at promoting agrarian exports. The support mechanisms operate within a sector-wide export vector and are managed by the Netherlands Enterprise Agency. Instead, there is a wide range of programs aimed at medium and small entrepreneurs. Also, all without exception, support programs are characterized by reasonable pragmatism. So, the tools for SME consulting and marketing assume that the entrepreneur himself agrees to bear a certain part of the costs. 
The German experience also shows that the introduction of agricultural attaché institutes can indeed be considered a quality tool to support agricultural exports by the state. At the same time, the maximum efficiency of the application of this tool will be possible only with the systematic development and cooperation of various institutional units.

\section{CONCLUSIONS AND DISCUSSION}

Ukraine is currently only taking the first steps to form its own institutional network to support exports. Based on the experience of best international practices in the operation of effective export support and promotion networks, several basic principles can be noted, compliance with which will allow building a more efficient and sustainable system:

1. The state shall ensure the ordering and general coordination of export promotion programs, as well as provide tools to facilitate the navigation of business between the institutional parts of the export support system.

2. General coordination will strengthen interdepartmental efforts to represent Ukraine's economic interests around the world. Building a global network of local offices in foreign markets provides better protection and a competitive presence in the global market.

3. Access to finance remains a pressing issue for Ukrainian companies seeking to export to other countries, as such access in the most purchasing markets with the highest buying potential is one of the key competitive advantages.

4. Online services and informational Internet portals also play a significant role in export promotion activities. Certain matters and inquiries are quite typical and frequent and have a significant degree of formalization, which allows the interested company to independently obtain information support through interactive tools.

5. The main driving force in foreign markets is, first of all, the company's (exporter) own efforts. Well-known tools for presenting the organization on the Internet are an important factor in their promotion. Website development and active management of social networks are the main resources for presenting the organization and disseminating information about services and opportunities that can be obtained by business.

6. Quality and effective promotion of services begins with the development of marketing strategy, which determines the direction of development of the organization, as well as a clear list and packages of services, including sound pricing policy (on how to position their services to provoke interest of business representatives).

7. An important area of work of organizations for their promotion, as well as defining and securing a place in the market is to form a communication strategy that allows to first identify customers, target audience and partners, and afterwards to choose effective communication channels and form a basic message to each interested party to cooperation.

8. Taking into consideration the main problems and challenges that NGOs and institutions face, in order to strengthen their market position, it is necessary to improve the quality of their export support services, which is manifested in the competence of employees and the formation of relevant services for SMEs. In particular, in order to provide quality services, it is required to use the developed methodological materials on export activities in Ukraine, as well as to have staff specializing in legal issues - the international legal framework.

9. Providing financial support to enterprises entering new markets is one of the new possible tools to support exports in Ukraine. The functions of accumulation and distribution of funds may be entrusted to institutions and organizations dealing with foreign economic issues.

\section{LIST OF REFERENCES}

1. Agritrade Ukraine Project. 2020. Analytical Report of Institutional Export Support in Ukraine. Available at https://cutt.ly/xEAWQAK (accessed on 28/09/2021)

2. Agritrade Ukraine Project. 2021. Review of researches and best practices on smes export support: government and institutional experience. Available at https://cutt.ly/3EAErGI (accessed on 28/09/2021)

3. Export Promotion Office. 2019. Study of business priorities for export activities. Research report, Export Promotion Office.

4. HM Government. 2018. Export Strategy: supporting and connecting businesses to grow on the world stage. Available at https://cutt.ly/kR7JQen (accessed on 29/09/2021)

5. Jansen, M., Lanz, R. 2013. Skills and Export Competitiveness for Small and Medium-Sized Enterprises. World Trade Organization, pp. 19.

6. Surugiua, M. R., Surugiu, C. 2015. International Trade, Globalization and Economic Interdependence between European Countries: Implications for Businesses and Marketing Framework. Procedia Economics and Finance, Vol. 32, pp. 131-138. https://doi.org/10.1016/S2212-5671(15)01374-X

7. OECD/WTO. 2019. Aid for Trade at a Glance 2019: Economic Diversification and Empowerment. https://doi.org/10.1787/18ea27d8-en

8. Zhu, S., Fu, X. 2013. Drivers of export upgrading. World Development, Vol. 51, pp. $221-233$. https://doi.org/10.1016/j.worlddev.2013.05.017

9. Ukraine Investment \& Trade Facilitation Center. 2019. Current needs of Ukrainian exporters to support their activities in European and other foreign markets. Available at https://cutt.ly/HEAEl7Z (accessed on 28/09/2021)

10. Ukrainian Food Association. 2021. Materials of the conference «B2B Online Trade Conference». Available at https://cutt.ly/yEATKmH (accessed on 29/09/2021) 